\title{
Global Challenges of Financial Inclusion
}

The author: Christoph Kreiterling is a Research Associate at the University College London's Centre for Blockchain Technologies, a PhD student at the Technical University of Chemnitz and a Senior Officer for Innovations in Financial Technology at the German Federal Financial Supervisory Authority (BaFin). This article solely reflects the author's personal opinion and does not reflect the official position of the German Federal Financial Supervisory Authority (BaFin).

Financial inclusion (Fl) aims to ensure access of the unbanked and underbanked, especially in low-income countries, to formal financial services such as payment services, saving services, credit services and insurance services. Representatives from 90 low-income countries have formed the Alliance for Financial Inclusion (AFI) aiming to foster FI for the 2.6 billion unbanked worldwide (Alliance for Financial Inclusion, 2014). However, the world is not only giving special attention to the question of whether people are banked, but also to how they access financial services. This article covers the global challenges of FI and their potential solutions by highlighting the following aspects: identification, financial literacy, rural and gender inequalities as well as cashless payments and transaction accounts. Furthermore, it shows as an example the Nigerian experience of digital saving.

\section{Lack of identification documents}

In finance, identity is vital for authentication purposes. Identification can be analog (paper), digitalized or digital. All these ways of identification are prone to frauds. Digital identity adopts Know Your Customer (KYC) regulations in order to preclude intentional and unintentional money laundering as well as financial frauds. How can KYC achieve that? It covers data on customer acceptance policy, procedures of customer identification (identity and address), risk management and transaction monitoring (Ketkar et al., 2014). Collating these data in collaboration with digital technologies, banks prevent anonymous accounts and detect risky transactions. Still, identity verification is not 100 percent safe and digital inequality carries some limitations with respect to the financial services as in the case of refugees (Yu et al., 2018).

Banks are increasingly collaborating with fintechs, that aim to replace the traditional methods of delivering financial services by digital methods. Moreover, efforts are made to create digital lockers. An example of such digital lockers is DigiLocker, a platform for verifying and issuing documents (Petare et al., 2015). DigiLocker relies on online accessing of information using two elements: repositories that are 
the electronic documents added by issuers as well as access gateways that secure the requester's access to these documents. Accordingly, it ensures privacy as well as authenticity and pr events the entering of fake documents.

\section{Poor financial literacy}

Financial literacy is the ability to process economic information and make informed decisions about financial planning, wealth accumulation, debt and pensions (Lusardi and Mitchell, 2014). According to the same research, only 30 percent of the US population can answer three basic financial literacy questions about compound interest, inflation and diversification correctly. To individuals, financial literacy promotes financial wellbeing because it helps them plan for retirement (Lusardi, 2015). Similarly, financially knowledgeable investors can react timely to fluctuations in the market and they tend to leave with the early indicators of crisis to save their capital (Guiso and Viviano, 2014). Based on these findings, agencies should disseminate financial knowledge. For this purpose, communication with customers through chatbots providing such financial knowledge could prove to be helpful. Additionally, finance and mathematical training courses in high school helped students making better financial decisions (Cole et al., 2015). These courses also minimized the dependence on nonstudent debt and ameliorated repayment conduct among young American students (Brown et al., 2016). Governments may also consider leading social campaigns to increase public awareness about the benefits of financial inclusion.

\section{Poor rural and gender inequalities}

A survey that assessed the consumption of formal financial services revealed higher levels of financial exclusion in rural areas as opposed to urban areas ( $\mathrm{Pal}$ and Pal, 2014). Rural unbanking is due to the high costs of providing financial services, difficult geographical access and financial illiteracy. Researchers found that gender inequality also existed and female-led households accessed formal financial services eight percent less than their counterparts led by males (Ghosh and Vinod, 2017). Again, the researchers explained this discrepancy by higher educational levels and wage rates of males in comparison to females. Therefore, females and rural areas should be in a special focus to increase competency and access to financial services.

Moving from rural and gender inequality, researchers estimated the impact of technology on the low income population. The researchers held interviews with participants with relatively low weekly revenues in order to analyze the role of technology in financial inclusion. According to the findings, technology may worsen the current state as the participants disclosed some in securities concerning the use of new technology: fears of attacks through online platforms, lack of confidence regarding the financial status 
and privacy concerns about disclosing financial information to organizations (Vines et al., 2014). A possible solution to address this aspect could therefore be to foster digital literacy accordingly.

\section{Promoting cashless payments}

Remittances, which are the inflows migrants send to their home countries, are the second most pivotal contributor to external investment in developing countries. They are what connects these countries to the global financial system (Agarwal and Horowitz, 2002). Remittances act as a financial intermediary in this process, which is why certain governments facilitate theses inflows. However, some researchers argued that countries must reach a threshold of economic growth so that advances could be significant (Azman-Saini et al., 2010). Bhattacharya et al. (2018) have evaluated the impact of remittances on the depth of finance in 57 of the top remittance recipient countries, including developing as well as developed countries. Their findings stress that there is a significant relationship between remittances and economic development in the long run (Bhattacharya et al., 2018). Moreover, they find that cashless payment supported remittances to a significant extent.

Digital or cashless payments deemed superior to cash payments. Compared to cash payments, digital payments have less cost of social transfer and less burden on governments. Generally speaking, cashless payments provide rapid access to formal financial services. They can mitigate the aforementioned problem of gender inequality because owning accounts is effortless (Klapper and Singer, 2014). In 2003, the city of London introduced digital ticketing for buses instead of paper tickets. In order to study the impact of this digital payment method on the money's social function, researchers interviewed bus drivers and passengers. To passengers, cashless payments decreased boarding times and reflected positively on the quality of service. To drivers, this system made it no longer necessary to carry cash, nor did they need to deliver money at the end of the day. Moreover, it also limited the contact between drivers and passengers. The I atter impacted the drivers' wellbeing and concentration (Pritchard et al., 2015).

On the other hand, traditional banking through local branches secures work opportunities for the youth. Completing transactions through digital banking may lead to higher unemployment. The Standard Bank of South Africa has left 1200 unemployed individuals after shutting down its 91 branches and turning to digital banking (Awosanya, 2019).

\section{Promoting the use of transaction accounts}

Cashless payments propel the tendency to promote transparency in financial services. Finance entities have been used to detect fraudulent activities manually using addresses, accounts of the users etc. This methodology deemed inaccurate given that fraudsters apply more advanced methods. Therefore, 
finance companies integrated traditional methods with machine learning techniques like Fuzzy Logic and Bayesian Networks. Despite the high costs, Bayesian Networks are clear, automatic and simple to use (Wiese and Omlin, 2009). Other researchers reported that finance accounts might rely on data mining, especially on algorithms for fraud detection (West and Bhattacharya, 2016). Due to their benefits, these technologies are worth considering. Furthermore, transaction accounts provide full-time access to liquidity, creditworthiness and other financial information. Given these information, the customer can make more informed financial decisions.

\section{Digital saving service in Nigeria}

Policymakers and providers of financial services should take measures to overcome the challenges of financial inclusion. Fintechs should work in line with banks to digitalize services. Nigeria is one of the countries that adopted communication and information technology to digitalize its financial se $r$ vices. Services encompass online transactions, mobile and prompt payments, electronic payment of bills, automatic clearance of cheques, ATMs (Automated Teller Machines) etc. Of these, researchers found that mobile payment was effective in alleviating poverty in rural areas of Nigeria (Ayo et al., 2011). So, what are the reasons for this development in Nigeria? The people of Nigeria lost trust in their banking systems after the economic crisis. As a result an online saving platform called Piggybank.ng was launched. It aims to help saving money with six percent annual return. Piggybankers can set a minimum duration during which they cannot withdraw any funds. Despite the fact that saving services form just one aspect of $\mathrm{Fl}$, a few more platforms continued to appear entailing ALAT (Nigeria's first digital-only bank), Diamond Bank's eSUSU (automated digital saving scheme) etc. (Adeshokan, 2018). Another successful example is the 62 percent (700 million) increase in the number of bank account holders between 2011 and 2014 thanks to mobile technology (Demirguc-Kunt et al., 2015). This clearly shows that a useful way to address $\mathrm{Fl}$ is by using digitalization with a heavy focus on mobile applications and digital automated processes with a minimum of human interactions. 


\section{References}

Adeshokan, O. (2018). Digital Savings Tool Give Nigerian Banks a Run for their Money. Retrieved from: Digital Savings Tool Give Nigerian Banks a Run for their Money.

Agarwal, R., and Horowitz, A. W. (2002). Are international remittances altruism or insurance? Evidence from Guyana using multiple-migrant households. World Development, 30(11), 2033-2044.

Alliance for Financial Inclusion. (2014). 2014 Maya Declaration Report: Measurable Goals with Optimal $\begin{array}{llll}\text { Impact. } & \text { Retrieved } & \text { from: } & \text { https://www.afi- }\end{array}$ global.org/sites/default/files/publications/2014_maya_declaration_progress_report_final_low_res.pdf. Awosanya, Y. (2019). Why the Nigerian banking industry may not take the fully digital leap anytime soon. Retrieved from: https://techpoint.africa/2019/03/27/nigerian-banking-industry-takefull-digital-leapsoon/.

Ayo, C. K., Adewoye, J. O., and Oni, A. A. (2011). Framework for Mobile Money Implementation in Nigeria. Journal of African Research in Business \& Technology, 1-8. Retrieved from: https:// doi.org/10.5171/2011.117860.

Azman-Saini, W. N. W., Law, S. H., and Ahmad, A. H. (2010). FDI and economic growth: New evidence on the role of financial markets. Economics Letters, 107(2), 211-213.

Bhattacharya, M., Inekwe, J., and Paramati, S. R. (2018). Remittances and financial development: empirical evidence from heterogeneous panel of countries. Applied Economics, 50(38), 4099-4112. Retrieved from: https://doi.org/10.1080/00 036846.2018.1441513.

Brown, M., Grigsby, J., van der Klaauw, W., Wen, J., and Zafar, B. (2016). Financial Education and the Debt Behavior of the Young. Review of Financial Studies, 29(9), 2490-2522. Retrieved from: https://doi.org/10.1093/rfs/hhw006.

Cole, S., Paulson, A., and Shastry, G. K. (2015). High School Curriculum and Financial Outcomes: The Impact of Mandated Personal Finance and Mathematics Courses. Journal of Human Resources, 51(3), 656-698. Retrieved from: https://doi. org/10.3368/jhr.51.3.0113-5410r1.

Demirguc-Kunt, A., Klapper, L., Singer, D., and Van Oudheusden, P. (2015). The Global Findex Data base 2014: Measuring Financial Inclusion around the World. Policy Research Working Papers. The World Bank. Retrieved from: https:// doi.org/10.1596/1813-9450-7255.

Ghosh, S., and Vinod, D. (2017). What Constrains Financial Inclusion for Women? Evidence from Indian Micro data. World Development, 92, 60-81. Retrieved from: https://doi.org/10.1016/j. worlddev.2016.11.011. 
Guiso, L., and Viviano, E. (2014). How much can financial literacy help? Review of Finance, 19(4), 13471382.

Ketkar, S. P., Shankar, R., and Banwet, D. K. (2014). Telecom KYC and mobile banking regulation: An exploratory study. Journal of Banking Regulation, 15(2), 117-128.

Aktuell 1

Klapper, L., and Singer, D. (2014). The opportunities of digitizing payments.

Lusardi, A. (2015). Financial literacy: Do people know the ABCs of finance? Public Understanding of Science, 24(3), 260-271.

Lusardi, A., and Mitchell, O. S. (2014). The Economic Importance of Financial Literacy: Theory and Evidence. Journal of Economic Literature, 52(1), 5-44. Retrieved from: https://doi. org/10.1257/jel.52.1.5. Pal, R., and Pal, R. (2014). Income related inequality in financial inclusion and role of banks: evidence on financial exclusion in India. Indira Gandhi Institute of Development Research.

Petare, P., Mohite, P., and Joshi, M. (2015). Digilocker (Digital Locker - Ambitious Aspect of Digital India Programme.). GE-International Journal of Management Research, 3 (6), 299-308.

Pritchard, G., Vines, J., and Olivier, P. (2015). Your Money's No Good Here: The Elimination of Cash Payment on London Buses. Proceedings of the 33rd Annual ACM Conference on Human Factors in Computing Systems - CHI '15. ACM Press. Retrieved from: https://doi.org/10.1145/ 2702123.2702137.

Vines, J., Dunphy, P., and Monk, A. (2014). Pay or delay: the role of technology when managing a low income. Proceedings of the 32nd Annual ACM Conference on Human Factors in Computing Systems CHI '14. ACM Press. Retrieved from: https://doi.org/10.1145/2556288.2556961.

West, J., and Bhattacharya, M. (2016). Intelligent financial fraud detection: A comprehensive review. Computers \& Security, 57, 47-66. Retrieved from: https://doi.org/10.1016/j.cose.2015. 09.005.

Wiese, B., and Omlin, C. (2009). Credit Card Transactions, Fraud Detection, and Machine Learning: Modelling Time with LSTM Recurrent Neural Networks BT - Innovations in Neural Information Paradigms and Applications. In M. Bianchini, M. Maggini, F. Scarselli, and L. C. Jain (Eds.) (pp. 231-268). Berlin, Heidelberg: Springer Berlin Heidelberg. Retrieved from: https://doi.org/ 10.1007/978-3-642-04003-0_10. Yu, B., Ndumu, A., Mon, L. M., and Fan, Z. (2018). E-inclusion or digital divide: an integrated model of digital inequality. Journal of Documentation. Retrieved from: https://doi.org/10.1108/jd-102017-0148. 